\title{
Severe Respiratory Syncytial Virus Infection
}

\section{Yasuyo Kashiwagi ${ }^{1} \cdot$ Toshihiro Nakayama $^{1} \cdot$ Masahiro Kimura $^{1} \cdot$ Tomoko Maeda $^{1}$ • Soken $\mathrm{Go}^{1} \cdot$ Hisashi Kawashima ${ }^{1} \cdot$ Akihito Sawada $^{2} \cdot$ Tetsuo Nakayama $^{2}$}

Received: 20 June 2019 / Accepted: 4 November 2019 / Published online: 21 December 2019

(C) The Author(s) 2019

To the Editor: We previously reported a case of twin neonates with severe respiratory syncytial virus (RSV) infection [1]. Here we describe a 26-d-old boy with severe RSV infection and a 16-mo-old boy with RSV infection who died suddenly.

The first case is a 26-d-old boy who was born at $36 \mathrm{wk}$ and $4 \mathrm{~d}$ of gestation. His birth weight was $2874 \mathrm{~g}$, and he showed respiratory distress with left pneumothorax and was intubated for $8 \mathrm{~d}$. He developed coughing and sneezing on day 25 and was admitted to our ward on day 26. The RSV rapid assay, based on immunochromatography with nasal fluid (Check RSV; Alfresa, Japan) was positive. His severe respiratory distress required mechanical ventilation from day 27 to day 41 .

The second case is a 16-mo-old boy who was completely healthy until this episode. He was coughing and sneezing for several days before his sudden death. He had a high fever and developed convulsions for $1 \mathrm{~min}$ and was found in cardiopulmonary arrest an hour later. He was referred to our emergency room, but resuscitation was unsuccessful. The result of the RSV rapid assay using nasal fluid was positive.

The patients' nasopharyngeal aspirate samples obtained in the acute phase were analyzed by real-time RT-PCR [2], which showed high levels of RSV type B, at $4.4 \times 10^{5}$ and $2.4 \times 10^{3}$ copies/ $\mu \mathrm{g}$ viral RNA in the first and second patient, respectively.

We measured the viral load in 36 children with not severe RSV infection. The average load were $4.5 \times 10^{4}$ copies $/ \mu \mathrm{g}$ viral RNA (data not shown). In our present cases, the amount of RSV found in the neonate was higher than that that in the young child with sudden death.

Yasuyo Kashiwagi

hoyohoyo18@hotmail.com

1 Department of Pediatrics and Adolescent Medicine, Tokyo Medical University, 6-7-1 Nishishinjuku, Shinjuku-ku, Tokyo 160-0023, Japan

2 Laboratory of Viral Infection, Kitasato Institute for Life Sciences, Kitasato University, Tokyo, Japan
Kakimoto et al. demonstrated that an extreme elevation of IL-6 might predict the risk for sudden death in normally developed children with RSV infection [3]. However, the mechanism of rapid progression of RSV-induced sudden death remains to be elucidated.

Regardless of the amount of RSV, unexpected complications such as central nervous system infection and dysfunction of the host immune system may happen in a fatal case [4].

\section{Compliance with Ethical Standards}

Conflict of Interest None.

Source of Funding This work was partly supported by a Grant-in-Aid from the Japan Agency for Medical Research and Development (AMED) under Grant Number 19fk0108032.

Open Access This article is distributed under the terms of the Creative Commons Attribution 4.0 International License (http:// creativecommons.org/licenses/by/4.0/), which permits unrestricted use, distribution, and reproduction in any medium, provided you give appropriate credit to the original author(s) and the source, provide a link to the Creative Commons license, and indicate if changes were made.

\section{References}

1. Kashiwagi Y, Kimura M, Maeda T, et al. Viral features in a twin case of severe respiratory syncytial virus infection. Indian J Pediatr. 2019;86:389.

2. Hu A, Colella M, Tam JS, Rappaport R, Cheng SM. Simultaneous detection, subgrouping, and quantitation of respiratory syncytial virus a and B by real-time PCR. J Clin Microbiol. 2003;41:149-54.

3. Kakimoto Y, Seto Y, Ochiai E, Satoh F, Osawa M. Cytokine elevation in sudden death with respiratory syncytial virus: a case report of 2 children. Pediatrics. 2016;138:pii:e20161293.

4. Xu L, Gao H, Zeng J, et al. A fatal case associated with respiratory syncytial virus infection in a young child. BMC Infect Dis. 2018;18. https://doi.org/10.1186/s12879-018-3123-8.

Publisher's Note Springer Nature remains neutral with regard to jurisdictional claims in published maps and institutional affiliations. 